Revista Brasileira de Farmacognosia Brazilian Journal of Pharmacognosy 23(1): 124-131, Jan./Feb. 2013

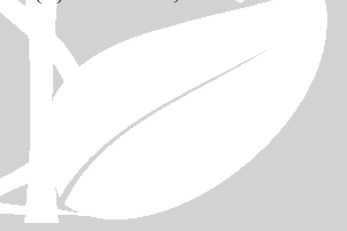

Article

Received 30 Jun 2012

Accepted 5 Sep 2012

Available online 16 Nov 2012

Keywords:

antiallodynic

anti-inflammatory

gallic acid

Phyllanthus niruri

spray dried powders

ISSN 0102-695X

DOI: $10.1590 / \mathrm{S} 0102-695 \mathrm{X} 2012005000133$

\section{Anti-inflammatory, antiallodynic effects and quantitative analysis of gallic acid in spray dried powders from Phyllanthus niruri leaves, stems, roots and whole plant}

\author{
Angélica G. Couto, ${ }^{* 1}$ Candida A. L. Kassuya, ${ }^{2}$ João B. Calixto, ${ }^{3}$ \\ P. R. Petrovick ${ }^{4}$
}

\begin{abstract}
${ }^{1}$ Programa de Pós-graduação em Ciências Farmacêuticas, Universidade do Vale do Itajaí, Brazil,

2Programa de Mestrado em Ciências da Saúde, Faculdade de Ciências da Saúde, Universidade Federal da Grande Dourados, Brazil,

${ }^{3}$ Departamento de Farmacologia, Centro de Ciências Biológicas, Universidade Federal de Santa Catarina, Brazil,

${ }^{4}$ Programa de Pós-graduação em Ciências Farmacêuticas, Faculdade de Farmácia, Universidade Federal do Rio Grande do Sul, Brazil.
\end{abstract}

\begin{abstract}
The anti-inflammatory and antiallodynic effects of spray dried powders starting from leaves, stems, roots, the mixture of leaves and stems, as well as the whole plant aqueous solutions of Phyllanthus niruri L., Phyllanthaceae, were assessed. Gallic acid, used as chemical marker, was quantified by HPLC in the spray dried powders. Carrageenan-induced inflammatory and allodynic responses in the mouse paw were used as pharmacological models. Quantitative and qualitative differences among chemical composition of different herb parts were observed. The oral administration of leaves or leaves plus stems spray dried powders (100 $\mathrm{mg} / \mathrm{kg}$ ) significantly inhibited the carrageenan-induced allodynic effect ( $42 \pm 5$ and $54 \pm 3 \%$, respectively). Additionally, the spray dried powders of leaves significantly reduced carrageenan-induced paw oedema $(35 \pm 6 \%)$. The spray dried powders of roots, stems, or the mixture of leaves, stems and roots $(100 \mathrm{mg} / \mathrm{kg}$, p.o. $)$ did not exhibit antiallodynic or antioedematogenic effect in the same model. In conclusion, differences in the chemical composition of spray dried powders from $P$. niruri are reflected in their in vivo pharmacological actions. Despite of a direct relationship of anti-inflammatory and antiallodynic effects with the gallic acid content had been observed, especially in the spray dried powders of leaves, the use of spray dried powders of leaves plus stems showed to be more effective, suggesting a synergic effect between their constituents.
\end{abstract}

\section{Introduction}

Phyllanthus niruri L., Phyllanthaceae, is a little shrub found both in tropical and subtropical countries. Several species from this genus are used worldwide in folk medicine for diverse therapeutic purposes. Pre-clinical pharmacological studies carried out with extracts and purified compounds from Phyllanthus species support most of their reported uses in folk medicine (Calixto et al., 1998). The popular uses of Phyllanthus species reported the treatment of dysentery, gonorrhea, urinary discharges, kidney and bladder stones (Unander et al., 1995). Besides its traditional use, other pharmacological properties were also investigated such as hypoglycemic (Hukeri et al.,
1988; Navarro et al., 2004), anti-hepatotoxic (Prakash et al., 1995; Naaz et al., 2007), antimalarial (Tona et al., 1999), antinociceptive (Santos et al., 1995), antiinflammatory (Kassuya et al., 2003, 2005, 2006), antiviral (Ogata et al., 1992; Qian-Cutrone et al., 1996), hypolipidemic (Khanna et al., 2002), antihyperuricemic (Murugaiyah \& Chan, 2009) and as wound healing (Shanbhag et al., 2010).

Most pharmacological properties for $P$. niruri have been reported using the whole plant, since Phyllanthus species are commonly small herbs and they are employed in this manner in folk medicine, and several actives constituents that have been identified and isolated from $P$. niruri, such as flavonoids, alkaloids, terpenes and lignans (Calixto et 
al., 1998; Kassuya et al., 2003, 2005, 2006). However, the Brazilian Pharmacopoea Comission published a Monograph describing the aerial parts as the official drug (Farmacopéia Brasileira, 2003) and gallic acid as one of its chemical markers.

Gallic acid has been successfully used as a chemical marker for the quality control of aqueous extracts of $P$. niruri, through a validated method using HPLC (De Souza et al., 2002). Taking into account the best stability and the highest technological value of the spray dried powder derivative, which was earlier reported by Soares (1997) and Soares et al. (1998), this type of herb extract has been studied as an intermediate product for granulation, tableting and coating technologies (Couto et al., 2001; De Souza et al., 2007; 2009a,b; Spaniol et al., 2009).

Considering that aqueous infusions of $P$. niruri whole plant are reported by traditional medicine (Navarro et al., 2004; Sumathi \& Parvathi, 2010), as well as the best quality usually associated to a spray dried product, in the present study it was attempted to evaluate the antiinflammatory and antiallodynic properties of aqueous spray dried powders derived from leaves, stems, roots, aerial parts and whole plant aqueous solutions.

\section{Material and Methods}

\section{Chemicals, drugs and reagents}

Colloidal silicon dioxide (Aerosil 200 ${ }^{\circledR}$ ) were purchased from Evonik-Degussa (São Paulo, Brazil); acetonitrile (HPLC grade), phosphoric acid and gallic acid (R. Ph. Eur.) were obtained from Merck (São Paulo, Brazil); water was obtained from Milli-Q system (Millipore, USA) with resistivity above $18.0 \Omega . \mathrm{m}$. Carrageenan, dexamethasone, phosphate buffered saline (PBS), hexadecyltrimethyl ammonium bromide (HTAB), $\mathrm{N}, \mathrm{N}$-dimethylformamide and 3,3,3 tetramethylbenzidine (TMB) were purchased from Sigma (St. Louis, USA); hydrogen peroxide $\left(\mathrm{H}_{2} \mathrm{O}_{2}\right)$ and anhydrous sodium acetate was obtained from Vetec (Rio de Janeiro, Brazil) and Tween $80^{\circledR}$ was purchased from Labsynth (São Paulo, Brazil).

\section{Plant material}

The separated leaves, stems and roots of Phyllanthus niruri L., Phyllanthaceae, were purchased from Quimer Ltda (São Paulo, Brazil), dried at $40^{\circ} \mathrm{C}$ for a week in an air oven and reduced in a knife mill (Retsch SK1). A voucher specimen (ICN 111765) of P. niruri is deposited in the herbarium of the UFRGS Botanical Department.

Spray dried powders (SDP)
Dried and ground leaves (L), stems (S), roots $(\mathrm{R})$, leaves plus stems $(\mathrm{L}+\mathrm{S})$ or the whole plant $(\mathrm{L}+\mathrm{S}+\mathrm{R})$ from $P$. niruri $\mathrm{L}$. were used as starting materials for aqueous extraction $(7.5 \% \mathrm{w} / \mathrm{v})$ by decoction for $15 \mathrm{~min}$ under reflux (Soares et al., 1998). After cooling, the extract was pressed (Hafico 5L, Germany) and filtered under vacuum. Each solution plus $30 \%(\mathrm{w} / \mathrm{w})$ colloidal silicon dioxide in relation to its dried residue (1.97, $0.85,0.56,1.60$ and $1.10 \%$ from $\mathrm{L}, \mathrm{S}, \mathrm{R}, \mathrm{L}+\mathrm{S}$ and $\mathrm{L}+\mathrm{S}+\mathrm{R}$ solutions, respectively) was spray dried using a Mini-spray Dryer (Büchi 190, Flawil, Switzerland) with two components nozzle and co-current flow, nozzle aperture of $0.7 \mathrm{~mm}$, spraying pressure of 200 $\mathrm{kPa}$, flow of $3 \mathrm{~mL} / \mathrm{min}$, inlet temperature of $145 \pm 2{ }^{\circ} \mathrm{C}$ and outlet temperature of $105 \pm 2{ }^{\circ} \mathrm{C}$ (Soares, 1997).

\section{HPLC analysis}

The analysis was concluded using a Shimadzu (Kyoto, Japan) liquid chromatograph equipped with a pump (LC-10AD), a gradient controller (FCV-10AL), an auto sampler (SIL-10A) and a UV/VIS detector (SPD-10A), controlled by CLASS LC-10 software. The column was a RP-18 LiChrospher 250 x 4 mm i.d., $5 \mu \mathrm{m}$ particle diameter (Merck, Darmstadt, Germany). A pre-column Shimadzu (10 x $4 \mathrm{~mm}$ i.d.) packed with Bondapak C18 $125 \AA$ (Waters, Milford, USA) was employed. The chromatographic separation was carried out using a mobile phase with phosphoric acid $1 \%$ (w/w) as solvent $\mathrm{A}$ and acetonitrile:phosphoric acid 1\% $(\mathrm{w} / \mathrm{w})(50: 50(\mathrm{v} / \mathrm{v}))$ as solvent B at a flow rate of 0.6 $\mathrm{mL} / \mathrm{min}$. The gradient program was as follows: $22-24 \%$ B (7 min $), 24-40 \%$ B (10 min), 40-100\% B (8 min), $100-22 \%$ B $(15 \mathrm{~min})$. The peaks were detected at 275 $\mathrm{nm}$ and identified by comparison of the retention time with standard gallic acid (De Souza et al., 2002).

Gallic acid was dissolved in acetonitrile:water $(20: 80 \mathrm{v} / \mathrm{v})$ to produce concentrations and filtered through $0.45 \mu \mathrm{m}$ membrane (Millipore, Bedford, USA) prior to injection. The calibration curve was fitted by linear regression.

Amounts of 116.30, 426.78, 726.87, 94.59 and $65.43 \mathrm{mg}$ of $\mathrm{L}, \mathrm{S}, \mathrm{R}, \mathrm{L}+\mathrm{S}$ and $\mathrm{L}+\mathrm{S}+\mathrm{R}$ SDP respectively were weighed and dissolved in $100 \mathrm{~mL}$ of distilled water. The assay samples were prepared diluting $3 \mathrm{~mL}$ of each SDP solution to $25 \mathrm{~mL}$ with acetonitrile:water $(20: 80 \mathrm{v} / \mathrm{v})$. Each sample $(20 \mu \mathrm{L})$ was injected three times.

The concentration of gallic acid in the SDP $\left(\mathrm{C}_{\mathrm{GASDP}}\right)$ was calculated using equation 1 :

$$
C_{G A S D P}(\mu g / m g)=\frac{C_{G A}(\mu g / m L) \times D F}{C_{S D P}(m g / m L)}
$$

where $\mathrm{C}_{\mathrm{GA}}$ is gallic acid concentration from the 
calibration curve, DF is the dilution factor (833.33) and $\mathrm{C}_{\mathrm{SDP}}$ is the concentration of each SDP in the sample.

\section{Pharmacological studies}

\section{Animals}

Male Swiss mice (25-35 g) were kept in chambers with controlled temperature $\left(22 \pm 1^{\circ} \mathrm{C}\right)$, under a $12 \mathrm{~h}$ light-dark cycle (lights on at 6:00 am), humidity $60-80 \%$ and free access to food and water. The studies were carried out in accordance with the demands of the Ethical Committee for Animal Experimentation of the Federal University of Santa Catarina (263/CEUA).

\section{Drug and extract administration}

Animals received oral administration of SDP extract $(100 \mathrm{mg} / \mathrm{kg}) 1 \mathrm{~h}$ before or subcutaneous injection of dexamethasone $4 \mathrm{~h}$ before carrageenan injection. Control animals were treated with $30 \%$ of Aerosil $200^{\circledR}$ in saline $(10 \mathrm{~mL} / \mathrm{kg}$, p.o. $)$.

\section{Induction and measurement of paw oedema}

Mice were injected intraplantarly $(50 \mu \mathrm{L})$ with carrageenan $(1 \%)$ into the right hind paw. The contralateral paw was injected with $50 \mu \mathrm{L}$ of sterile phosphate buffered saline (PBS) and was used as control. Paw oedema development was measured at different time intervals $(3,4,8$, and $24 \mathrm{~h})$ by plethysmometry (Ferreira, 1979; Henriques et al., 1987), in a digital plethysmometer (Ugo Basile, Comerio, Italy). The difference between the right and left paws was quantified as oedema volume $(\mu \mathrm{L})$.

\section{Myeloperoxidase activity}

Neutrophil infiltration into the mouse plantar tissue was evaluated indirectly by measuring the myeloperoxidase activity (MPO) (De Young et al., 1989; Kassuya et al., 2003). Briefly, $4 \mathrm{~h}$ after carrageenan injection, the subcutaneous tissue of the injected paws was removed and homogenized in $5 \%(\mathrm{w} / \mathrm{v})$ of $80 \mathrm{mM}$ phosphate buffer ( $\mathrm{pH} 5.4$ ) containing $0.5 \%$ HTAB. The homogenate was centrifuged at $12,000 \times \mathrm{g}$ and $4{ }^{\circ} \mathrm{C}$ for $20 \mathrm{~min}$. Aliquots $(30 \mu \mathrm{L})$ of each supernatant were mixed with $100 \mu \mathrm{L}$ of phosphate buffer $80 \mathrm{mM}, 85 \mu \mathrm{L}$ of phosphate buffer $0.22 \mathrm{M}$ and $15 \mu \mathrm{L}$ of $0.017 \% \mathrm{H}_{2} \mathrm{O}_{2}$ in a 96-well plate. The reaction was triggered with 20 $\mu \mathrm{L}$ of TMB (dissolved in dimethylformamide). The plate was kept at $37{ }^{\circ} \mathrm{C}$ for $3 \mathrm{~min}$, after it was put on ice and the reaction was stopped by adding $30 \mu \mathrm{L}$ of sodium acetate $1.46 \mathrm{M}$ ( $\mathrm{pH} 3.0)$. The enzymatic activity was determined by measuring the optical density at 630 $\mathrm{nm}$ and was expressed as $\mathrm{mOD} / \mathrm{mg}$ of protein in the sample.

\section{Carrageenan-induced mechanical allodynia}

Mechanical allodynia was measured by using $0.4 \mathrm{~g}$ von Frey filaments which produces a response frequency of about $15 \%$. Mice were further acclimatized in individual clear Plexiglas boxes on an elevated wire mesh platform to allow the access to the ventral surface of the hind paws. The frequency of withdrawal was determined before and after carrageenan $(1 \%)$ injection at appropriate time points. In order to obtain data purely derived from the treatments on the allodynia induced by carrageenan, the maximal inhibition (MI) values were calculated as the difference between the basal values of vehicle or drug-treated animals and its respective controls (Kassuya et al., 2003).

\section{Data analysis}

Results are expressed as the mean $\pm \mathrm{SD}$ or SEM. The statistical difference between groups were determined by analysis of variance (ANOVA) followed by Student-Newman-Keul's, Dunnett's multiple comparison tests, or by means of Student's t-test when appropriate. Statistical significance was defined as $p<0.05$.

\section{Results and discussion}

The previous developed HPLC method for aqueous extracts of Phyllanthus niruri L., Phyllanthaceae (De Souza et al., 2002) also showed to be suitable for the analysis of the spray dried powders (SDP). This could be seen through the reproductions of the chromatographic pattern of the chosen markers (Figure 1). Gallic acid (peak 1), the flavone (peak 2), and the gallic acid derivative (peak 3 ) were detected in all samples (Figure 1). The retention times of $6.58 \pm 0.02,19.73 \pm 0.09$ and $21.16 \pm 0.07$ for gallic acid, peak 2 and 3, respectively, and chromatographic profiles (Figure 1) were in agreement with results found by Lionço et al. (2001) and De Souza (2004). In previous work, authors demonstrated the chromatographic profiles of the aqueous extract of leaves, stems, their mixtures and roots. Therefore, neither the drying process nor the adding of colloidal silicon dioxide interfered in the qualitative composition of the SDP components. The unique qualitative differences were caused by the plant part used as starting material for the SDP, suggesting also quantitative modifications among the different SDP.

For quantitative purposes, the chromatographic parameters ( $\mathrm{k}^{\prime}, \alpha$, Rs and $\left.\mathrm{N}\right)$ were evaluated to validate the method previous developed by De Souza et al. (2002) also for the SDP samples. 
Independent of the origin of the sample $(\mathrm{L}, \mathrm{S}$, $\mathrm{R}$, and their mixtures) the chromatographic parameters matched the required acceptation criteria established by international validation recommendations (FDA-CDER, 2001; ICH, 2005). The capacity factor values (k') were greater than 1 and smaller than 5 ; selectivity factors $(\alpha)$ were greater than 1 demonstrating adequate separation of the peaks; resolution values (Rs) between peaks 1 an 2 and peaks 2 and 3 indicated poor overlapping and consequently less loss of area among subjacent peaks, which allow an efficient quantitative evaluation.

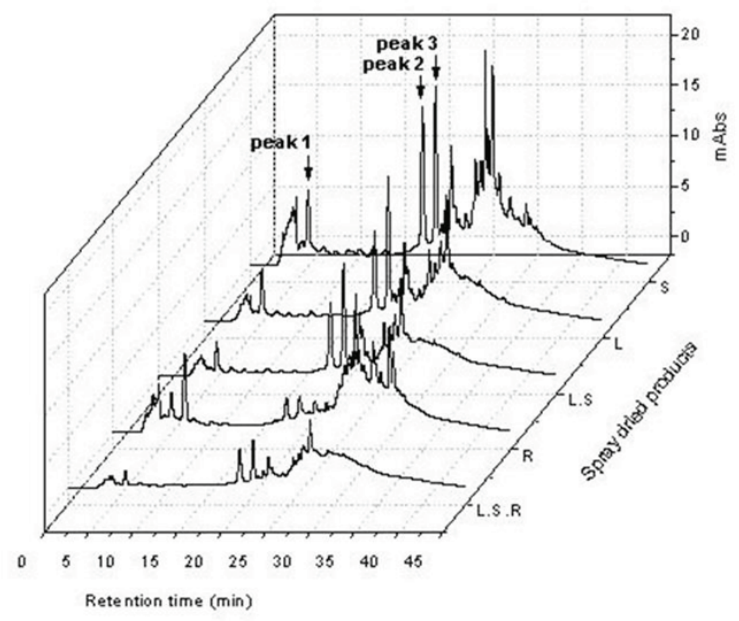

Figure 1. HPLChromatographic profiles of Phyllanthus niruri spray dried powders of leaves (L), stems (S), mixture of aerial parts $(\mathrm{L}+\mathrm{S})$, roots $(\mathrm{R})$, and the whole plant $(\mathrm{L}+\mathrm{S}+\mathrm{R})$, as previously diluted samples yielding final concentrations of $139.60,512.15,113.51,872.24$, and $78.51 \mu \mathrm{gmL}^{-1}$ of $\mathrm{L}, \mathrm{S}$, $\mathrm{L}+\mathrm{S}, \mathrm{R}$ and $\mathrm{L}+\mathrm{S}+\mathrm{R}$ respectively.

From the statistical evaluation of the calibration curve for the external standard gallic acid resulted the equation $\mathrm{A}(\mathrm{mV} \bullet \mathrm{s})=138.85(\mathrm{mV} \mathrm{s})+92050.25 \cdot \mathrm{C}_{\mathrm{GA}}(\mathrm{mV}$ $\left.\mathrm{s} / \mathrm{mg} \mathrm{mL}^{-1}\right)$, where $\mathrm{A}=$ peak area and $\mathrm{C}_{\mathrm{GA}}=$ concentration of gallic acid $\left(\mathrm{r}^{2}=0.9999\right)$, confidence intervals $=-1032.74$ to 1310.44 . The response was throughout linear to the concentration and no deviations due to inherent errors were detected (ANOVA and residue test results not shown).

The SDP from leaves (L) and stems (S), as well their mixture $(\mathrm{L}+\mathrm{S})$, presented very similar chromatographic profiles (Figure 1), but the SDP from leaves (L) expressed the highest yield of gallic acid and other major substances (Table 1), as already previously demonstrated (Lionço et al., 2001).

The SDP from leaves plus stems were originated from a mixture of the aerial parts containing $80 \%$ by weight of the leaves. The measured concentration of gallic acid in this SDE could be considered equivalent to the calculated value from the separated parts (difference $=8.54 \%$ ).

Although the proportion of roots in the purchased plant material was not controlled, it seems clear that the quantity of marker substances is dependent on the presence of leaves.

Table 1. Concentration assay of gallic acid, flavone (peak 2) and gallic acid derivative (peak 3 ) in the spray dried powders (SDP) from the leaves (L), stems (S), roots (R) or mixtures of leaves and stems $(\mathrm{L}+\mathrm{S})$ and whole plant $(\mathrm{L}+\mathrm{S}+\mathrm{R})$.

\begin{tabular}{lccc}
\hline \multirow{2}{*}{ SDP } & Gallic acid & \multicolumn{2}{c}{ Concentration $( \pm \mathrm{sd}) \mu \mathrm{g} \mathrm{mg}^{-1}$} \\
\cline { 3 - 4 } & & Peak 2 & Peak 3 \\
\hline $\mathrm{L}$ & $6.20 \pm 0.09$ & $15.25 \pm 0.54$ & $19.18 \pm 0.52$ \\
$\mathrm{~S}$ & $2.15 \pm 0.04$ & $6.70 \pm 0.17$ & $5.99 \pm 0.15$ \\
$\mathrm{R}$ & $0.61 \pm 0.01$ & $0.590 \pm 0.004$ & $0.55 \pm 0.05$ \\
$\mathrm{~L}+\mathrm{S}$ & $4.80 \pm 0.12$ & $14.85 \pm 0.38$ & $18.02 \pm 0.43$ \\
$\mathrm{~L}+\mathrm{S}+\mathrm{R}$ & $3.39 \pm 0.03$ & $10.62 \pm 0.25$ & $10.10 \pm 0.21$ \\
\hline
\end{tabular}

Stronger qualitative and quantitative differences were especially observed in the chromatographic profile of the roots (Figure 1). This fact is probably assigned to the presence of other relevant compounds for specific physiological function in the root.

Intraplantar injection of carrageenan (1\%) produced a time-dependent mechanical allodynia associated with oedema formation at the ipsilateral paw. At the same dose that induced paw oedema, carrageenan enhanced significantly the mechanical withdrawal response, an effect that started at $3 \mathrm{~h}$ and persisted for up 24 h post injection (Figures 2 and 3).

Figure 2 also shows that the oral pretreatment of animals with SDP of leaves $(\mathrm{L})$ or leaves plus stems $(\mathrm{L}+\mathrm{S})$ $(100 \mathrm{mg} / \mathrm{kg}), 1 \mathrm{~h}$ before the test or carrageenan injection, resulted in a significant inhibition of the allodynic effect induced by carrageenan injection. Inhibitions of $42 \pm 5 \%$ and $54 \pm 3 \%$ were observed, respectively. In contrast, the SDP prepared from the leaves plus stems plus roots $(\mathrm{L}+\mathrm{S}+\mathrm{R})$, stems $(\mathrm{S})$, or roots $(\mathrm{R})$ of $P$. niruri did not significantly alter the allodynia induced by carrageenan after $3 \mathrm{~h}$ (Figure 2).

The treatment with SDP of leaves plus stems $(\mathrm{L}+\mathrm{S})$ from $P$. niruri also significantly decreased the mechanical allodynia $(48 \pm 6 \%)$ in the von Frey test, after $4 \mathrm{~h}$. However, the other SDP did not reveal any anti-allodynic properties. Additionally, not significant inhibition of allodynia after the treatment with SDP was observed, both at 8 and $24 \mathrm{~h}$ after carrageenan injection (Figure 2).

At the same dose, only the SDP with leaves (L) was effective in inhibiting the paw oedema formation $(35 \pm 6.0 \%)$, when evaluated $3 \mathrm{~h}$ after intraplantar injection of carrageenan (Figure 3). No significant inhibition of paw oedema was observed at 4,8 and $24 \mathrm{~h}$ following carrageenan injection (Figure 3). In addition, the inhibition observed in dexamethasone-treated group was $41 \pm 5.0 \%$ after $3 \mathrm{~h}$ of the injection of carrageenan in the paw (results 

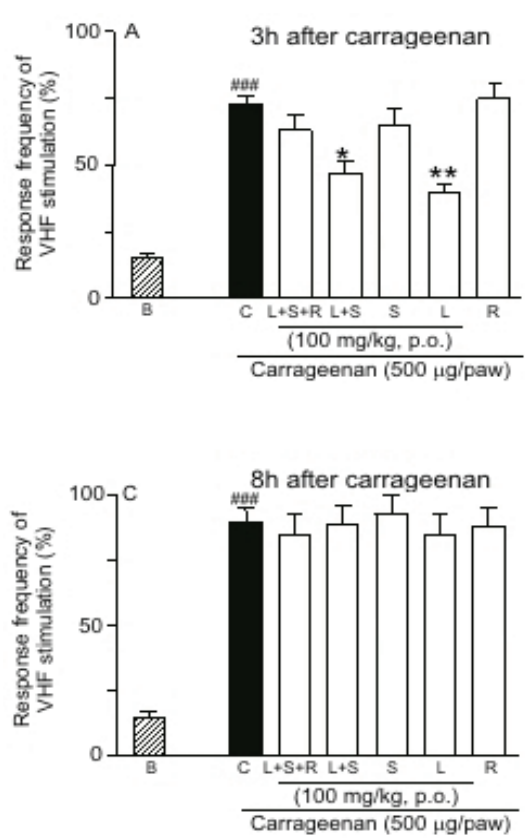
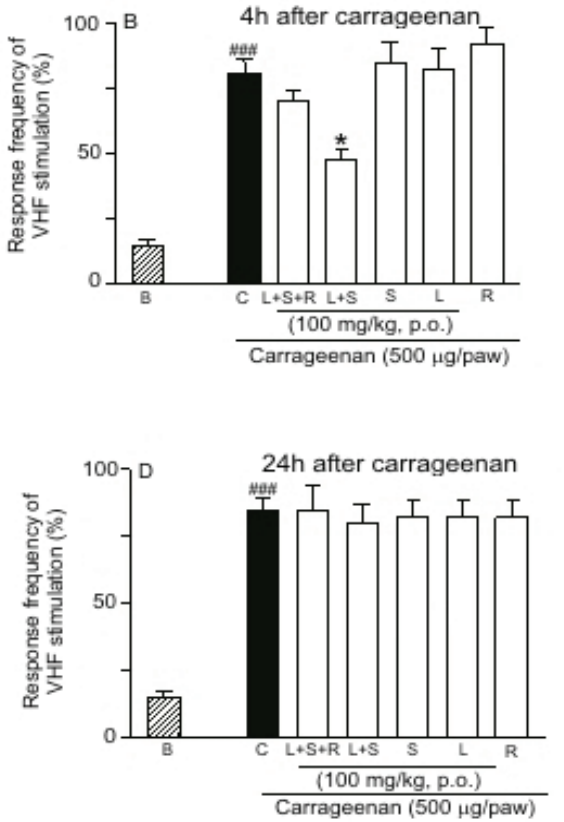

Figure 2. Effect of p.o. administration of SDP from the leaves (L), stems (S), roots (R) or mixtures of leaves and stems (L+S) and whole plant $(\mathrm{L}+\mathrm{S}+\mathrm{R})$ of Phyllanthus niruri on carrageenan induced-mechanical allodynia in mice. Groups of mice treated with extracts one hour before carrageenan were observed before (basal values) and at 3, 4, 8 and 24h after carrageenan injection. Each column represents the mean of seven animals and vertical lines show the SEM. Asterisks denote the significance levels. ${ }^{*} p<0.05$, ${ }^{*} p<0.01$, compared with the Cg plus vehicle-injected mice, ${ }^{\# \#} p<0.001$ vs baseline values (one-way ANOVA followed by Student-Newman-Keuls' test).
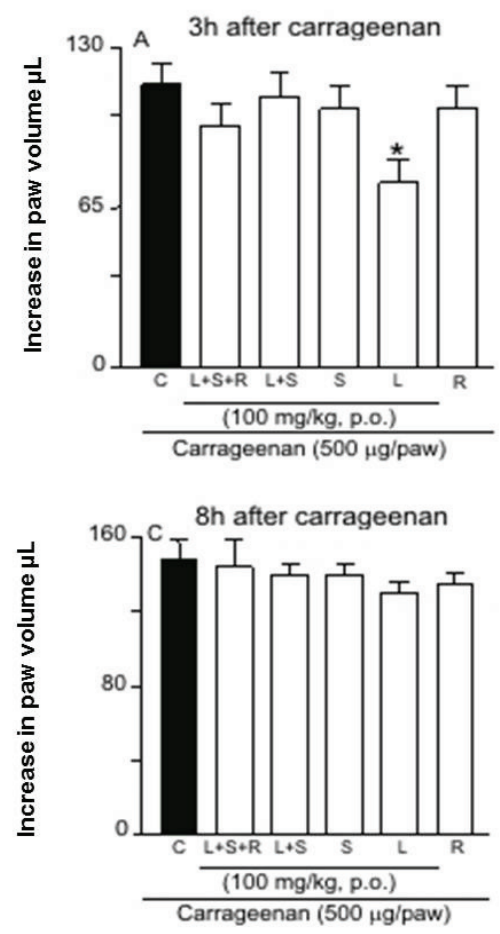
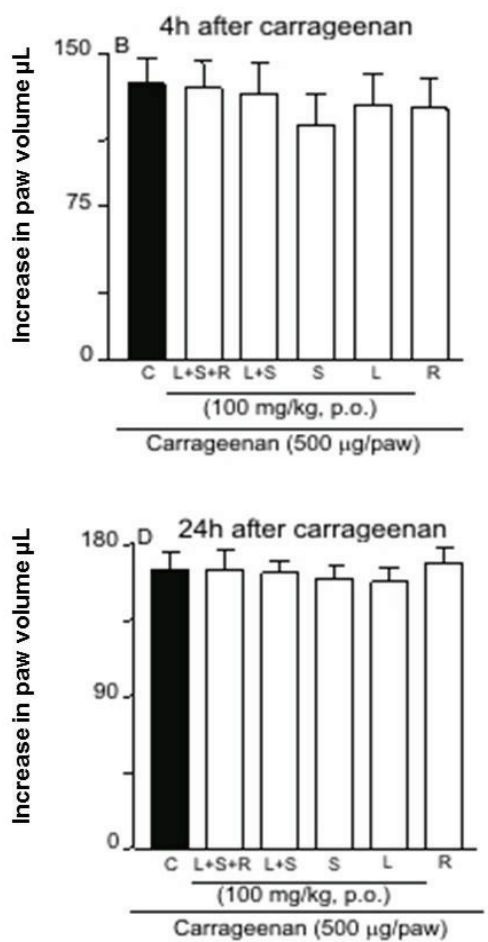

Figure 3. Effect of p.o. administration of SDP from the leaves (L), stems (S), roots (R) or mixtures of leaves and stems $(\mathrm{L}+\mathrm{S})$ and whole plant $(\mathrm{L}+\mathrm{S}+\mathrm{R})$ of Phyllanthus niruri carrageenan-induced paw oedema in mice. Groups of mice treated with extracts one hour before carrageenan were observed 3, 4, 8 and $24 \mathrm{~h}$ after carrageenan injection. Each column represents the mean of six animals and vertical lines show the SEM. Asterisks denote the significance levels. ${ }^{*} p<0.05$ compared with the Cg plus vehicle-injected mice (one-way ANOVA followed by Student-Newman-Keuls' test). 
was not shown).

The intraplantar injection of carrageenan (1\%) produced a significant (about 5 -fold) increase in the myeloperoxidase activity levels ( $4 \mathrm{~h}$ post-injection) when compared with the myeloperoxidase values in PBS-injected paws. Dexamethasone $(0.5 \mathrm{mg} / \mathrm{kg}$, s.c $)$, a drug known to produce marked properties was used as positive control and reduced increase in myeloperoxidase activity (Table 2). The acute oral treatment with SDP of leaves (L) or leaves plus stems $(\mathrm{L}+\mathrm{S})(100 \mathrm{mg} / \mathrm{kg})$ did not significantly alter the myeloperoxidase activity when compared with saline-treated animals (Table 2). The MPO is an enzyme present, mainly, in neutrophils. So, the notably increasing in the MPO activity reflects the neutrophil migration into the tissue during inflammation and is an indirect evidence for neutrophil influx. Furthermore, dexamethasone, but not SDP of leaves $(\mathrm{L})$ or leaves plus stems $(\mathrm{L}+\mathrm{S})$, inhibited the $\mathrm{Cg}$ induced leukocyte migration into the paw mice. These results showed that dexamethasone interfere in signs of inflammatory process while SDP of leaves (L) or leaves plus stems $(\mathrm{L}+\mathrm{S})$ only reduced oedema but not leukocyte migration.

Table 2. Effect of spray dried powders (SDP) from leaves (L) and leaves plus stems $(\mathrm{L}+\mathrm{S})$ of Phyllanthus niruri on myeloperoxidase activity in the paw of carrageenan-injected mice (time point of $4 \mathrm{~h}$ ).

\begin{tabular}{lc}
\hline Group & $\mathrm{mOD} \bullet 10^{3} / \mathrm{mg}$ of protein \\
\hline Naïve & $144 \pm 5.6$ \\
Dexametasone & $180 \pm 7.5^{* *}$ \\
Control & $689 \pm 3.0^{\#}$ \\
SDP (L) & $653 \pm 8.6$ \\
SDP (L + S) & $750 \pm 10.8$ \\
\hline
\end{tabular}

Data are expressed as Optic Density units (mOD) means \pm SEM; $n=5$ mice per group. ${ }^{* *} p<0.01$ vs control, Dunnett's multiple comparison test; ${ }^{*} p<0.001$ vs normal paw, Student's $\mathrm{t}$ - test.

As it was observed in the present study, the different composition among the SDP related to their herb part origin influenced significantly on their in vivo pharmacological action. In a first moment, it seems that there is a direct relationship among the pharmacological effects and the yield of gallic acid. Gallic acid is already known to have analgesic activity, especially related to the o-dihydroxy group of gallic acid, which is involved in the scavenging of superoxide anions (Kroes et al., 1992; Krogh et al., 2000).

The qualitative differences observed in the chromatographic profiles of roots SDP did have no positive effect on the pharmacological action. It is reasonable that the poor pharmacological response after administration of the SDP containing roots ( $\mathrm{R}$ or whole plant) is assigned to the dilution effect caused by the lowest proportion of leaves and consequently the lowest gallic acid concentration.

Our results show that both the leaves and the stems extracts of $P$. niruri contain higher concentrations of gallic acid. It is important to observe that the same rapid onset pattern of response was observed by the extract from the leaves of $P$. niruri on $\mathrm{Cg}$-induced allodynia (Figure 2) or against $\mathrm{Cg}$-induced oedema formation (Figure 3). As shown in Figure 3, the extract from the leaves $P$. niruri only inhibited at $3 \mathrm{~h}$, but not at $4 \mathrm{~h}$ time-points, in $\mathrm{Cg}$-induced oedema formation or in $\mathrm{Cg}$-induced allodynia response.

In conclusion, the results presented in this study showed that different botanical origin parts of $P$. niruri L., Phyllanthaceae, exhibited quantitative and qualitative differences among chemical composition that directly influence in anti-inflammatory and antiallodynic actions of this plant. Single oral administration of SDP from leaves or aerial parts, but not roots, stems, or the mixture of leaves, stems and roots, significantly inhibited the allodynia and oedema formation in $\mathrm{Cg}$ model. These activities should be related to the gallic acid concentration, which is higher in the leaves $\operatorname{SDP}(6.20 \mu \mathrm{g} / \mathrm{mg})$. However, despite the lower gallic acid content, the use of SDP of leaves plus stem prolonged this action over $4 \mathrm{~h}$, being more effective than SDP of leaves itself, suggesting the occurrence of synergism, which corroborates the use of aerial parts together as starting materials for analgesic phytopharmaceutical purposes.

\section{Acknowledgments}

This work was supported by grants from CNPq, Brazil. The authors are grateful to Dr. Hartmut Derendorf for critical comment and assistance in preparing the manuscript.

\section{References}

Calixto JB, Santos ARS, Filho V, Yunes RA 1998. A Review of the plants of the genus Phyllanthus: their chemistry, pharmacology, and therapeutic potential. Med Res Rev 18: $225-258$.

Couto AG, Petrovick PR, Bassani VL, González Ortega G 2001. Technological characterization of Phyllanthus niruri spray dried extract. Acta Farm Bonaer 20: 189196.

De Souza TP, Holzschuh MH. Lionço MI, Ortega GG, Petrovick PR 2002. Validation of a LC method for the analysis of phenolic compounds from aqueous extract of Phyllanthus niruri aerial parts. J Pharm Biomed Anal 30: 351-356.

De Souza TP 2004. Desenvolvimento tecnológico e otimização de formas farmacêuticas sólidas contendo 
alto teor de produto seco por aspersão de Phyllanthus niruri L. (Euphorbiaceae). Porto Alegre, PhD Tese, Universidade Federal do Rio Grande do Sul.

De Souza TP, Martínez-Pacheco R, Goméz-Amoza JL, Petrovick PR 2007. Eudragit E as excipient for production of granules and tablets from Phyllanthus niruri L spray-dried extract. http://www. aapspharmscitech.org, accessed Sep 2012.

De Souza TP, Goméz-Amoza JL, Martínez Pacheco R, Petrovick PR 2009a. Development of granules from Phyllanthus niruri spray-dried extract. Braz J Pharm Sci 45: 669-675.

De Souza TP, Martínez-Pacheco R, Gómez-Amoza JL, Petrovick PR 2009b. Eudragit E as excipient for production of granules and tablets from Phyllanthus niruri L spray-dried extract. AAPS Pharm Sci Tech 8: E54-E60.

De Young LM, Kheifets JB, Ballaron SJ, Young JM 1989. Edema and cell infiltration in the phorbol estertreated mouse ear are temporally separate and can be differentially modulated by pharmacologic agents. Agents Actions 26: 335-341.

Farmacopéia Brasileira 2003. São Paulo: Atheneu.

FDA-CDER 2001. Food and Drug Administration, Center of Drug Evaluation and Research. Guidance for industry: Bioanalytical method validation. Rockville: CDER.

Ferreira SH 1979. A new method for measuring variations of rat paw volume. J Pharm Pharmacol 31: 648.

Henriques MG, Silva PM, Martins MA, Flores CA, Cunha FQ, Assreuy-Filho J, Cordeiro RS 1987. Mouse paw edema. A new model for inflammation? Braz J Med Biol Res 20: 243-249.

Hukeri VI, Kalyani GA, Kakrani HK 1988. Hypoglicemic activity of flavonoids of Phyllanthus fraternus in rats. Fitoterapia 59: 68-70.

ICH 2005-International Conference on the Harmonization of Technical Requirements for the Registration of Pharmaceuticals for Human Use - Harmonised tripartite guideline - Validation of analytical procedures: Text and methodology Q2(R1) [online] 2005, http://www.ich.org/LOB/media/MEDIA417. pdf, accessed May 2012.

Kassuya CAL, Silvestre AA, Rehder VLG, Calixto JB 2003. Anti-allodynic and anti-oedematogenic properties of the extract and lignans from Phyllanthus amarus in models of persistent inflammatory and neuropathic pain. Eur J Pharmacol 478: 145-153

Kassuya CAL, Leite DFP, Vilela de Melo L, Rehder VLG, Calixto JB 2005. Anti-inflammatory properties of extracts, fractions and lignans isolated from Phyllanthus amarus. Planta Med 71: 721-726.

Kassuya CAL, Silvestre A, Menezes-de-Lima O, Marotta DM, Rehder VLG, Calixto JB 2006. Antiinflammatory and antiallodynic actions of the lignan niranthin isolated from Phyllanthus amarus. Evidence for interaction with platelet activating factor receptor. Eur $J$ Pharmacol 546: 182-188.

Khanna AK, Rizvi F, Chander R 2002. Lipid lowering activity of Phyllanthus niruri in hyperlipemic rats. $J$ Ethnopharmacol 82: 19-22.

Kroes BH, van den Berg AJ, Quarles van Ufford HC, van Dijk H, Labadie RP 1992. Anti-inflammatory activity of gallic acid. Planta Med 58: 499-504.

Krogh R, Yunes RA, Andricopulo AD 2000. Structure-activity relationships for the analgesic activity of gallic acid derivatives. Farmaco 55: 730-735.

Lionço MIDS, De Souza TP, Petrovick PR 2001. Chromatographic evaluation of polyphenols in morphological organs from Phyllanthus niruri. Cad Farm 17: 117-120.

Murugaiyah V, Chan KL 2009. Mechanisms of antihyperuricemic effect of Phyllanthus niruri and its lignan constituents. J Ethnopharmacol 124: 233-239.

Naaz F, Javed S, Abdin MZ 2007. Hepatoprotective effect of ethanolic extract of Phyllanthus amarus Schum. et Thonn. on aflatoxin $\mathrm{B}_{1}$-induced liver damage in mice. $J$ Ethnopharmacol 113: 503-509.

Navarro M, Coussio J, Hnatyszyn O, Ferraro G 2004. Efecto hipoglucemiante del extracto acuoso de Phyllanthus sellowianus ("sarandí blanco") en ratones C57BL/K. Acta Farm Bonaer 23: 520-523.

Ogata T, Higuchi H, Mochida S, Matsumoto H, Kato A, Endo T, Kaji A, Kaji H 1992. HIV-1 reverse transcriptase inhibitor from Phyllanthus niruri. Aids Res Hum Retrov 8: 1937-1944.

Prakash A, Satyan KS, Wahi SP, Singh RP 1995. Comparative hepatoprotective activity of three Phyllanthus species, $P$. urinaria, $P$. niruri and $P$. simplex, on carbon tetrachloride induced liver injury in the rat. Phytother Res 9: 594-596.

Qian-Cutrone J, Huang S, Trimble J, Li H, Lin PF, Alam M, Klohr SE, Kadow KF 1996. Niruriside, a new HIV REV/RRE binding inhibitor from Phyllanthus niruri. J Nat Prod 59: 196-199.

Santos ARS, Filho VC, Yunes RA, Calixto JB 1995. Further studies on the antinociceptive action of the hydroalcoholic extracts from plants of the genus Phyllanthus. J Pharm Pharmacol 47: 66-71.

Shanbhag T, Amuthan A, Shenoy S, Sudhakar 2010. Effect Phyllanthus niruri Linn on burn wound in rats. Asian Pac J Trop Med 3: 105-108.

Soares LAL 1997. Padronização de extrato aquoso e desenvolvimento de produto seco por aspersão de Phyllanthus niruri L.-Euphorbiaceae (Quebra-Pedra). Porto Alegre, 96p. Dissertação de Mestrado, Programa de Pós-graduação em Ciências Farmacêuticas, Universidade Federal do Rio Grande do Sul.

Soares LAL, González Ortega G, Bassani VL, Petrovick PR 1998. Technological development of aqueous extracts from Phyllanthus niruri L. by using of factorial design. Cad Farm 14: 21-26. 
Spaniol B, Bica VC, Ruppenthal LR, Volpato MR, Petrovick PR 2009. Compressional behavior of a mixture of granules containing high load of Phyllanthus niruri spray-dried extract and granules of adjuvants: comparison between eccentric and rotary tablet machines. AAPS PharmSciTech 10: 1013-1023.

Sumathi P, Parvathi A 2010. Antimicrobial activity of some traditional medicinal plants. J Med Plants Res 4: 316321.

Tona L, Ngimbi NP, Tsakala M, Mesia K, Cimanga K, Apers S, De Bruyne T, Pieters L, Totté J, Vlietinck AJ 1999. Antimalarial activity of 20 crude extracts from nine African medicinal plants used in Kinshasa, Congo. $J$ Ethnopharmacol 68: 193-203.
Unander DW, Webster GL, Blumberg BS 1995. Uses and bioassays in Phyllanthus (Euphorbiaceae): compilation. Part 2. Subgenus Phyllanthus. J Ethnopharmacol 45: 1-18.

\section{*Correspondence}

\section{Angélica G. Couto}

Programa de Pós-graduação em Ciências Farmacêuticas, Universidade do Vale do Itajaí

Rua Uruguai 458, 88302-202 Itajaí-SC, Brazil

angelica@univali.br

Tel/Fax: +55 4733417932 